\title{
Sistem Pencatatan Dan Pendataan Manajemen Sumber Daya Manusia Dengan Model Scrum (Studi Kasus: Pt Bintang Trans Khatulistiwa)
}

\author{
Saepurrahman ${ }^{1}$, Aris Setiawan ${ }^{2}$, Inge Handriani ${ }^{3}$ \\ ${ }^{1.2 .3}$ Program Studi Sistem Informasi, Fakultas Ilmu Komputer, Universitas Mercu Buana \\ 141814110064@student.mercubuana.ac.id, ${ }^{241813110187 @ s t u d e n t . m e r c u b u a n a . a c . i d, ~}$ \\ ${ }^{3}$ Inge.handriani@mercubuana.ac.id ${ }^{3}$ \\ Jl. Raya Meruya Selatan, Kembangan, Jakarta, 11650. Indonesia
}

\begin{abstract}
Human resource management or commonly called Human Resource Development (HRD) is one of the most important parts of a company or organization. Because, the main focus of human resource management is to contribute to the success or failure of an organization or company. The duties and activities of HRD in a company are to deal with issues relating to the management of human resources in an organization (company). Management of human resource data at PT. Bintang Trans Khatulistiwa (BTK) is still manual, so companies have difficulty in obtaining information relating to human resources quickly and accurately. To deal with these problems, we propose making a Human Resource management information system, namely the Application of Recording and Data Collection System for Human Resource Management which later can help the HRD to carry out their duties, starting from the employee data collection process, attendance data collection, filing leave, payroll process or payroll and employee ratings to report generation, and can produce information that can be used for decision making for a manager. In developing this system using the Scrum method approach and using the cause effect diagram (fishbone) method as a basis for analyzing the problem, so that later solutions will be obtained for making the system in this research.
\end{abstract}

Abstrak - Manajemen sumber daya manusia atau biasa disebut Human Resource Development (HRD) merupakan salah satu bagian terpenting dalam suatu perusahan atau organisasi. Karena, fokus utama manajemen sumber daya manusia adalah memberikan kontribusi bagi sukses atau tidaknya suatu organisai atau perusahaan. Tugas dan kegiatan HRD dalam suatu perusahaan adalah menangani permasalahan-permasalahan yang berkenaan dengan pengelolaan sumber daya manusia pada sebuah organisasi (perusahaan). Pengelolaan data sumber daya manusia pada PT. Bintang Trans Khatulistiwa (BTK) masih bersifat manual, sehingga perusahaan kesulitan dalam memperoleh informasi yang berhubungan dengan sumber daya manusia secara cepat dan akurat. Untuk menangani permasalahan tersebut, maka kami mengusulkan pembuatan suatu sistem informasi manajemen Sumber Daya Manusia yaitu Aplikasi Sistem Pencatatan dan Pendataan Manajemen Sumber daya Manusia yang nantinya dapat membantu bagian HRD untuk menjalankan tugasnya, mulai dari proses pendataan karyawan, pendataan absensi, pengajuan cuti, proses payroll atau penggajian dan penilaian karyawan hingga pembuatan laporan, serta dapat menghasilkan informasi yang dapat digunakan untuk pengambilan keputusan bagi seorang manajer. Dalam pengembangan sistem ini menggunakan pendekatan metode Scrum dan menggunakan metode cause effect diagram (fishbone) sebagai dasar untuk melakukan analisa permasalahan, sehingga nantinya akan didapatkan solusi-solusi untuk pembuatan sistem pada penelitian ini. Keywords - Sistem informasi, sumber daya manusia, Scrum, Fishbone

\section{PENDAHULUAN}

Seiring perkembangan teknologi dan sitem informasi pada saat ini sudah begitu banyak merambah keberbagai segi kehidupan. Sehingga peranan teknologi informasi hampir tidak dapat dipisahkan dari kehidupan seharihari. Terlebih pada era globalisasi saat ini, teknologi informasi menempati peranan utama dalam kehidupan masyarakat. Penggunaan teknologi informasi berkembang dengan sangat cepat dan pesat. Di berbagai bidang kemajuan sistem berkembang menuju arah teknologi yang semakin baik [1]. Teknologi dan informasi merupakan dua hal yang tidak dapat dipisahkan. Hal ini terlihat dari proses untuk mendapatkan informasi yang dapat diperoleh secara cepat, tepat, dan akurat dengan didukung oleh kemajuan teknologi yang semakin canggih. Kemajuan teknologi ini membuat banyak organisasi dan instansi menggunakan teknologi berbasis komputer dan jaringan untuk membantu pekerjaannya karna bersifat efektif dan efisien [2].

Pemanfaatan teknologi informasi dalam pengelolaan dan manajemen sangatlah diperlukan 105 | http://www.jurnal.umb.ac.id/index.php/JSAI 
diberbagai aspek-aspek dalam perusahaan, Salah satunya pada bagian Manajemen sumber daya Manusia (HRD), karena dengan berbagai kelebihan dan kemudahan yang ditawarkan tentu akan meningkatkan afektivitas yang baik bagi suatu perusahaan dalam menjalankan roda bisnis perusahaannya. Pengelolaan human capital managemet yang dimaksudkan adalah bahwa perusahaan harus mampu untuk menyatukan persepsi atau cara pandang karyawan dan pimpinan perusahaan dalam rangka mencapai tujuan perusahaan antara lain melalui pembentukan mental bekerja yang baik dengan dedikasi dan loyalitas yang tinggi terhadap pekerjaannya, memberikan motivasi kerja, bimbingan, pengarahan dan koordinasi yang baik dalam bekerja oleh seorang pemimpin kepada bawahannya.

Banyak para pemimpin perusahaan kurang menyadari bahwa keuntungan yang diperoleh perusahaan sebenarnya berasal dari human capital, hal ini disebabkan aktivitas perusahaan lebih dilihat dari perspektif bisnis semata [3]. Perusahaan yang tumbuh baik dan berkembang akan menitik beratkan pada sumber daya manusia guna menjalankan fungsinya dengan optimal, Karena dalam Manajemen Sumber Daya Manusia (MSDM) atau Human Resources Department (HRD) terdapat fungsi tugas yang diantaranya adalah perekrutan dan penerimaan, pendidikan dan pelatihan, pengelolaan data yang berhubungan dengan karyawan serta penghentian dan administrasi benefit [4], sehingga manajemen sumber daya manusia disini harus mampu mengoptimalkan fungsinya dalam melaksanakan tugasnya, khususnya menghadapi dinamika perubahan lingkungan yang terjadi. Kepribadian merupakan bagian dari karakteristik umum yang ditampilkan individu dalam perilakunya, baik di tempat kerja maupun dalam kehidupan sehari-hari yang lahir sebagai hasil interaksi antara faktor genetik dan pengaruh lingkungan [5].

Peningkatan kinerja karyawan akan membawa kemajuan bagi perusahaan untuk dapat bertahan dalam suatu persaingan lingkungan bisnis yang tidak stabil [6]. Hal ini berarti bahwa meskipun terdapat peralatan canggih yang dimiliki tetapi tanpa didukung oleh human capital managemet yang handal untuk mengoperasionalkan maka hasilnya akan tetap sia-sia. Dalam sebuah perusahaan, bagian terpenting yang menangani sumber daya manusia adalah departemen SDM atau biasa disebut Human Resource Department (HRD). Karena, fokus utama manajemen sumber daya manusia adalah memberikan kontribusi bagi sukses atau tidaknya suatu organisai atau perusahaan. Sumber daya manusia yang berkualitas dan profesional merupakan faktor utama dalam membantu organisasi mencapai tujuan.

Apabila manajemen SDM pada departemen HRD tidak dilakukan dengan baik, maka perusahaan akan mengalami kemunduran atau bahkan dapat terjadi hal yang paling buruk yaitu berhentinya proses bisnis dan sebaliknya apabila manajemen SDM dilakukan dengan baik, maka hak dan kewajiban antara perusahaan dan tenaga kerja akan terpenuhi, sehingga seluruh elemen perusahaan akan saling mendukung untuk dapat tercapainya tujuan perusahaan. Karena sejatinya pengelolaan sumber daya manusia merupakan hal yang penting dalam pencapaian tujuan [7] [8].

Selain itu pula kedudukan sumber daya manusia pada posisi yang paling tinggi berguna untuk mendorong perusahaan menampilkan norma perilaku, nilai dan keyakinan sebagai sarana penting dalam peningkatan kinerjanya. Begitu pentingnya peranan sumber daya manusia dalam mengendalikan perusahaan sehingga peranan yang dimiliki melebihi peranan sumber daya lainnya. Karena apabila pada suatu perusahaan tidak terdapat pengelolaan sumber daya manusia yang tepat dan tanpa didukung oleh karyawan yang berkualitas, maka sumber daya lainnya seperti modal atau uang, alam dan teknologi tidak akan mencapai hasil yang optimum.

Apabila perusahaan memiliki pegawai yang banyak, dibutuhkan sistem yang terkomputerisasi untuk dapat membantu menyelesaikan permasalahan tersebut, sehingga informasi yang dibutuhkan dapat lebih cepat dan akurat. Dalam suatu perusahaan atau instansi pemerintahan kegiatan pendataan kepegawaian merupakan kegiatan yang umum dilakukan. Pendataan tersebut dilakukan untuk mengetahui informasi tentang data kepegawian dalam perusahaan. Kegiatan pengolahan data pegawai, merupakan kegiatan yang cukup menghabiskan waktu dan energi bagi pihak administrasi (HRD). Padahal kegiatan ini sangat penting untuk mengetahui identitas para pegawai [9].

Persaingan di dunia bisnis semakin kompetitif memacu perusahaan berupaya lebih keras dalam meningkatkan kualitas perusahaanya. Salah satu upaya meningkatkan kualitas sumber daya manusia adalah dengan melakukan pengukuran terhadap maksimal atau tidaknya seorang karyawan terhadap perusahaan melalui suatu penilaian kinerja karyawan. Pada saat ini pengolahan informasi mengenai kepegawaian pada PT 
Bintang Trans Khatulistiwa (BTK) hanya menggunakan program di Microsoft Excel dan Microsoft Word sebagai penyimpanan data - data mengenai kepegawaian dibagian kepegawaian (HRD). Namun aplikasi tersebut masih kurang optimal yaitu aplikasi tersebut hanya sebagai tempat penyimpanan data standar mengenai data pegawai yang bekerja di PT Bintang Trans Khatulistiwa, yang kemudian dilakukannya pengolahan data di Microsoft Excel, sehingga terdapat kelemahan-kelemahan yang terjadi dalam manajemen Sumber Daya Manusia.

Oleh karena itu diperlukan sebuah sistem informasi yang dapat membantu Bagian HRD dalam menjalankan tugasnya, salah satunya yaitu kegiatan dalam Pencatatan dan Pendataan kepegawian sehingga menjadi lebih efektif dan efesien, sehingga informasi yang di dapatkan akan lebih cepat dan akurat, yang nantinya data tersebut bisa dijadikan suatu acuan bagi seorang manajer atau pimpinan dalam pengambilan keputusan.

Berdasarkan pembahasan diatas dapat diidentifikasi permasalahannya yaitu:

1. Bagaimana membuat sistem pencatatan dan pendataan manajemen sumber daya manusia yang efektif dan efesien?

Batasan masalah dalam penelitian ini mencakup informasi kepegawaian yaitu pendataan pegawai, pendataan Absensi, pendataan pengajuan izin dan cuti, proses payroll atau penggajian, pendataan penilaian kinerja karyawan dan pendataan sanksi bagi karyawan yang dibutuhkan oleh bagian/departemen terkait, seperti informasi kepegawaian, dan form yang diperlukan untuk pendataan karyawan yang dilakukan oleh perusahaan (HRD). Dengan menentukan tujuan penelitian yaitu yang digunakan untuk evaluasi terhadap penilaian kinerja bagi PT Bintang Trans Khatulistiwa serta pengontrolan yang dilakukan pihak manajemen terhadap tenaga kerja dan semua informasi tentang kepegawaian.

\section{METODE PENELITIAN}

Penelitian dilakukan dengan menggunakan metode kualitatif deskriptif. Pada penelitian ini mengambil objek mengenai sistem pencatatan dan pendataan manajaemen sumber daya manusia yang diterapkan dalam PT Bintang Trans Khatulistiwa. Dengan pendekatan kualitatif dapat ditemukan data yang bersifat proses kerja, perkembangan suatu kegiatan, deskripsi yang luas dan mendalam, atau sekelompok orang dalam lingkungan kerjanya.

\section{Observasi}

Penelitian melakukan observasi terhadap HRD dan Kepala Bagian HRD, berinteraksi dengan mereka, berusaha memahami tentang lingkungan kerjanya, mencari tahu tentang alur proses bagian HRD dalam melakukan pendataan kepegawaian. Menganalisa permasalahan dilapangan yang berkaitan dengan proses pendataan karyawan. Dalam melakukan penelitian ini, yang menjadi subyek adalah beberapa informan yang dipilih oleh peneliti yang sekiranya dapat memberikan informasi yang diperlukan yaitu kepala bagian dan staf HRD.

\section{Wawancara}

Kegiatan wawancara dilakukan dengan tanya jawab secara langsung kepada kepala bagian HRD dan juga Staff HRD untuk mengetahui mekanisme proses pencatatan dan pendataan Kepegawaian dan mengolah data tersebut.

\section{Dokumenatsi}

Sumber kajian pustaka pada penelitian ini didasarkan pada acuan dan referensi pada Company Profile, Standard Operasional Procedure (SOP), dan formulir register pendataan pegawai yang masih berlaku saat ini. Pada tahap ini juga mengamati proses dalam pendataan manajemen sumber daya manusia yang sedang berlangsung di PT Bintang Trans Khatulistiwa. HRD memberikan dokumentasi perihal form yang saat ini sedang berjalan. Metode pengembangan sistem yang digunakan adalah pendekatan model SCRUM, Menurut Pressman (2010:82) Scrum adalah metode pengembangan peranti lunak secara cepat (agile). Prinsip scrum sesuai dengan prinsip-prinsip yang terdapat pada metode pengembangan peranti secara cepat yang digunakan untuk menuntun kegiatan pengembangan peranti lunak, seperti: pemenuhan kebutuhan, analisa, desain, dan penyampaian (delivery) [10]. 




Gambar 1 Alur Proses Scrum

Menurut Pressman (2010:83), di setiap tahap pengembangan, terjadi aktivitas kerja yang terlingkup di dalam suatu pola proses yang dinamakan sprint. Setiap pola proses yang terjadi, akan terdapat seperangkat kegiatan berikut:

a. Backlog

Sebuah rincian prioritas pada fitur-fitur yang akan dibangun pada suatu proyek. Isi pada fitur dapat ditambahkan setiap saat.

b. Sprints

Kumpulan aktivitas kerja yang dilakukan untuk memenuhi kebutuhan yang ditetapkan dalam backlog dan harus diselesaikan pada waktu yang telah ditentukan (biasanya 30 hari). Perubahan tidak dapat dilakukan pada proses sprint sehingga setiap tim akan bekerja di dalam lingkungan yang stabil.

c. Scrum Meeting

Pertemuan yang dilakukan setiap hari oleh Tim scrum untuk membahas apa yang telah dikerjakan sejak pertemuan terakhir, merencanakan dan membahas masalah-masalah yang ada (biasanya 15 menit).

d. Demos

Menujukan hasil fungsionalitas yang telah diimplementasikan sehingga dapat dievaluasi oleh pengguna. Demo harus berupa fitur-fitur yang telah diselesaikan sesuai dengan waktu yang telah ditetapkan.

Pada tahap analisa sistem, pada penelitian ini melakukan analisa menggunakan metode Analisa Fishbone, metode ini bisa menjadi solusi sebuah masalah. Diagram fishbone merupakan suatu alat visual untuk mengidentifikasi, mengeksplorasi, dan secara grafik menggambarkan secara detail semua penyebab yang berhubungan dengan suatu permasalahan. Konsep dasar dari diagram fishbone adalah permasalahan mendasar diletakkan pada bagian kanan dari diagram atau pada bagian kepala dari kerangka tulang ikannya. Penyebab permasalahan digambarkan pada sirip dan durinya. Kategori penyebab permasalahan yang sering digunakan sebagai start awal meliputi materials (bahan baku), machines and equipment (mesin dan peralatan), manpower (sumber daya manusia), methods (metode), Mother Nature/environment (lingkungan), dan measurement (pengukuran) [11].

Tahapan yang dilakukan dalam penelitian ini adalah sebagai berikut:

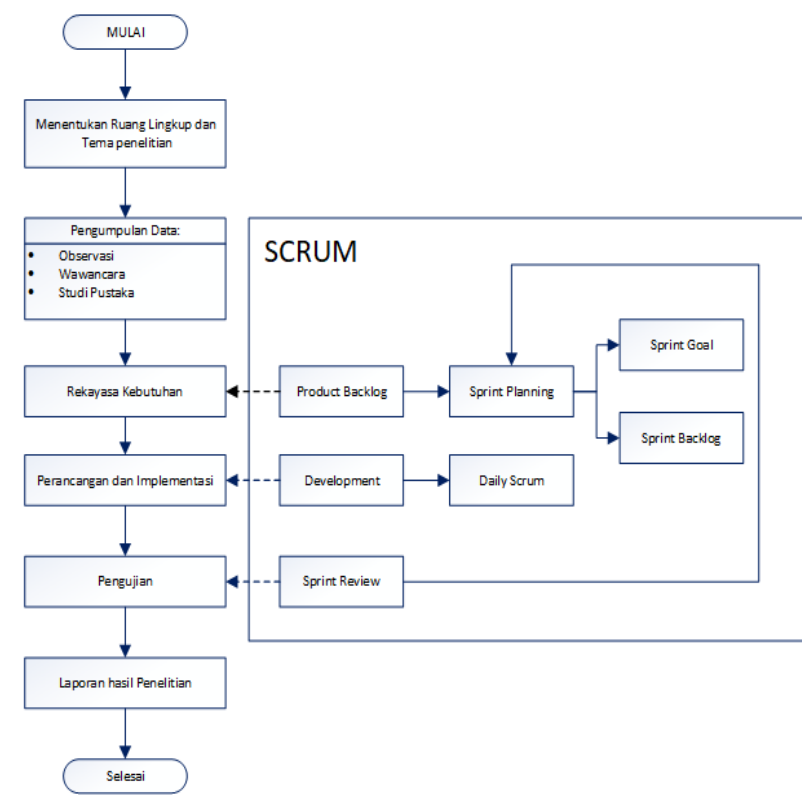

Gambar 2 Diagram Alur Penelitian

\section{HASIL DAN PEMBAHASAN}

1. Analisa sistem Berjalan

Bisnis proses pencatatan dan pendataan manajemen sumber daya manusia:

- Bagian HRD memberikan form registrasi pendataan pegawai kepada seluruh karyawan

- Karyawan mengisi form registrasi karyawan dengan lengkap dan benar

- Karyawan mengemblaikan form registrasi data pegawai kepada bagian HRD

- Bagian HRD merekap semua form registrasi data pegawai seluruh karyawan kedalam sebuah arsip.

- Bagian HRD melakukan pengecekan data apakah sudah lengkap atau belum, jika lengkap maka HRD melakukan penginputan 
data karyawan kedalam computer mengggunakan ms.excel, jika tidak lengkap maka bagian HRD meminta karyawan tersebut untuk melengkapi data.

- Bagian HRD mencetak Laporan data karyawan dan memberikan kepada manajer

- Manajer melihat laporan data karywan yang selanjutnya untuk di approve untuk kemudian oleh baguian HRD disimpen dalam arsip dokumen Data karyawan dibagian HRD.

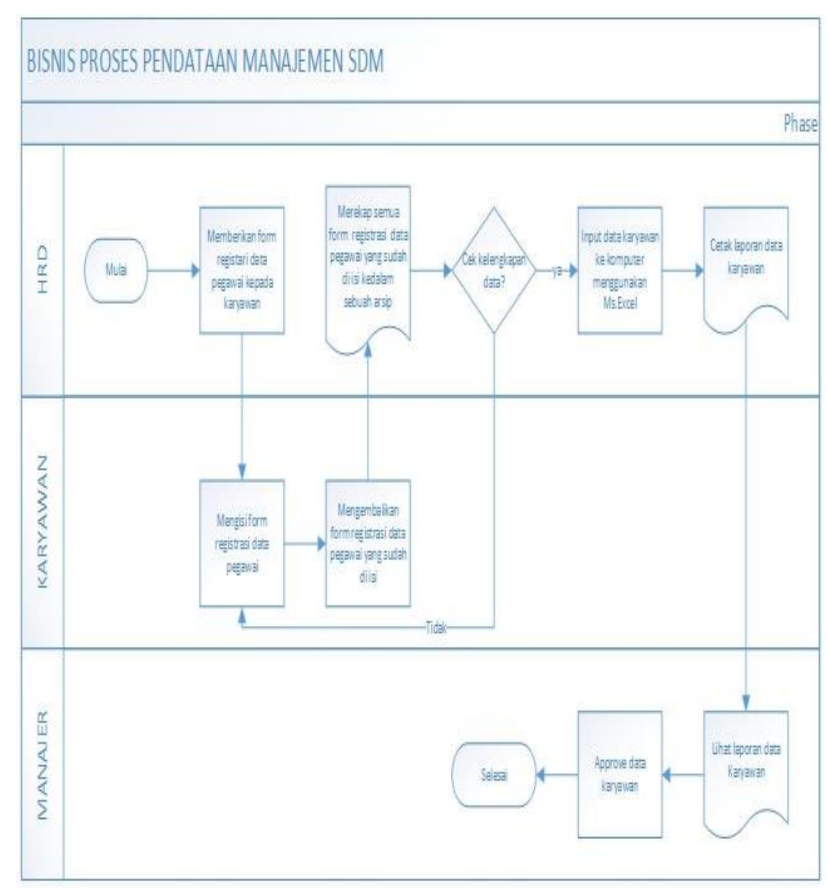

Gambar 3. Proses Bisnis Berjalan Pendataan Manjemen SDM

Dilihat dari proses sistem berjalan diatas dalam pencatatan dan pendataan manjemen sumber daya manusia oleh bagian HRD, maka dapat dianalisa permasalahan yang bisa timbul dengan menggunakan Analisa fishbone.

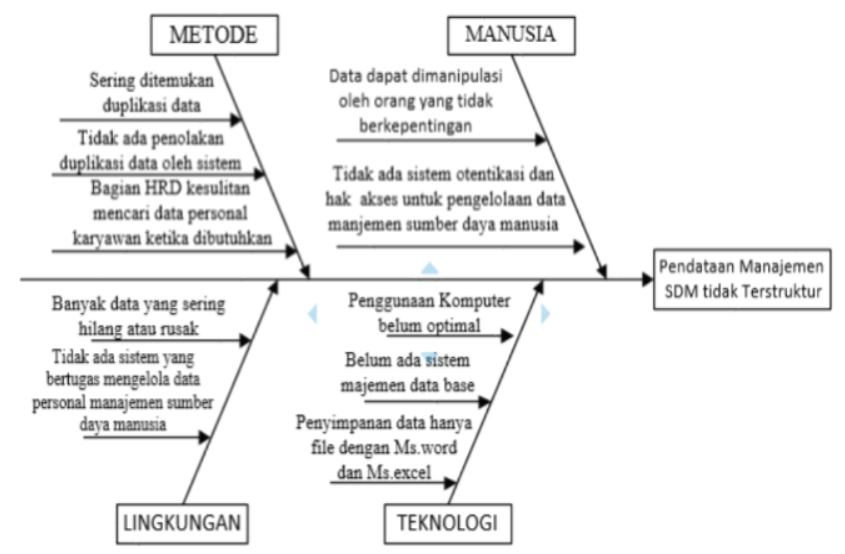

\section{Gambar 4 Analisa Fishbone}

Dari analisis fishbone diatas didapatkan bahwa sebab yang paling mungkin menyebabkan pengelolaan data personal manajemen sumber daya manusia yang tidak terstruktur dan terkomputerisasi dengan baik adalah sebagai berikut:

1. Tidak ada sistem otentikasi dan hak akses untuk pengelolaan data manjemen sumber daya manusia

2. Belum ada sistem manajemen data base

3. Tidak ada penolakan duplikasi data oleh sistem

4. Tidak ada sistem yang bertugas mengelola data personal manajemen sumber daya manusia yang terorganisir dan terkomputerisasi dengan baik

\section{Menentukan Product Backlog}

Langkah pertama dalam mengembangkan sistem menggunakan metode scrum adalah Product Backlog yaitu penentuan fitur apa saja yang akan dibuat pada sistem berdasarkan tingkat prioritas, mulai dari yang tersulit sampai dengan yang sangat tidak sulit. Berikut product backlog Aplikasi Sistem Pencatatan dan Pendataan Manajemen Sumber Daya Manusia:

\section{Tabel 1 Product backlog}

\begin{tabular}{|c|l|}
\hline No & \multicolumn{1}{|c|}{ Deskripsi Fitur } \\
\hline 1 & Membuat Sistem Login Admin (User) \\
\hline 2 & Membuat Tampilan Home \\
\hline 3 & $\begin{array}{l}\text { Membuat Sistem Input Form Data } \\
\text { Recruitment }\end{array}$ \\
\hline 4 & $\begin{array}{l}\text { Membuat Sistem Input Form Data Pegawai } \\
\text { Baru }\end{array}$ \\
\hline 5 & $\begin{array}{l}\text { Membuat Sistem Input Form Data Pegawai } \\
\text { dan SK }\end{array}$ \\
\hline 6 & Membuat Sistem Input Form Data Kehadiran \\
\hline 7 & $\begin{array}{l}\text { Membuat Sistem Input Form Data Penggajian } \\
\text { (Payroll) }\end{array}$ \\
\hline 8 & $\begin{array}{l}\text { Membuat Sistem Input Form Data Penilain } \\
\text { Kinerja }\end{array}$ \\
\hline 9 & Membuat Sistem Input Form Data Sanksi \\
\hline
\end{tabular}

\section{Menentukan Sprint Backlog}

Setelah Product Backlog dibuat, langkah selanjutnya yang dilakukan yaitu masuk kedalam tahap sprint. Dalam pembuatan sistem informasi ini dilakukan sprint sesuai dengan tahapan yang telah dibuat di product 
backlog sebelumnya. Tahapan sprint dikerjakan sesuai dengan tingkat prioritas tertinggi.

Tabel 2 Sprint 1 Login

\begin{tabular}{|c|c|c|c|}
\hline $\begin{array}{c}\text { Fitur } \\
\text { Backlog }\end{array}$ & Task & Pemilih Task & $\begin{array}{c}\text { Perkiraan } \\
\text { Waktu } \\
\text { (Jam) }\end{array}$ \\
\hline \multirow{6}{*}{$\begin{array}{c}\text { Membuat } \\
\text { Fitur } \\
\text { Login }\end{array}$} & $\begin{array}{c}\text { Desain } \\
\text { Database }\end{array}$ & $\begin{array}{l}\text { Database } \\
\text { Sistem }\end{array}$ & $2 \mathrm{Jam}$ \\
\hline & $\begin{array}{c}\text { Desain } \\
\text { Interface }\end{array}$ & $\begin{array}{l}\text { Analis } \\
\text { Sistem }\end{array}$ & $2 \mathrm{Jam}$ \\
\hline & $\begin{array}{l}\text { Coding } \\
\text { Front End }\end{array}$ & Programmer & $5 \mathrm{Jam}$ \\
\hline & $\begin{array}{c}\text { Coding } \\
\text { Back End }\end{array}$ & Programmer & $5 \mathrm{Jam}$ \\
\hline & Testing & $\begin{array}{l}\text { Project } \\
\text { Manager }\end{array}$ & 2 Jam \\
\hline & \multicolumn{2}{|c|}{ Total } & 16 \\
\hline
\end{tabular}

Sprint 1 terdiri dari 5 task dan memiliki total estimasi waktu sebanyak 16 jam. Setelah sprint 1 selesai dilaksanakan, maka dilanjutkan dengan sprint 2 yang dapat dilihat pada tabel berikut di bawah ini.

Tabel 3 Sprint 2 Home

\begin{tabular}{|c|c|c|c|}
\hline $\begin{array}{c}\text { Fitur } \\
\text { Backlog }\end{array}$ & Task & Pemilih Task & $\begin{array}{c}\text { Perkiraan } \\
\text { Waktu } \\
\text { (Jam) }\end{array}$ \\
\hline \multirow{4}{*}{$\begin{array}{l}\text { Membuat } \\
\text { Fitur Home }\end{array}$} & $\begin{array}{c}\text { Desain } \\
\text { Interface }\end{array}$ & Analis Sistem & $2 \mathrm{Jam}$ \\
\hline & $\begin{array}{l}\text { Coding } \\
\text { Front End }\end{array}$ & Programmer & $5 \mathrm{Jam}$ \\
\hline & $\begin{array}{c}\text { Coding } \\
\text { Back End }\end{array}$ & Programmer & $5 \mathrm{Jam}$ \\
\hline & \multicolumn{2}{|c|}{ Total } & 12 \\
\hline
\end{tabular}

Sprint 2 terdiri dari 3 task dan memiliki total estimasi waktu sebanyak 12 jam. Sprint ini membuat tampilan home pada aplikasi, Setelah sprint 2 selesai dilaksanakan, maka dilanjutkan dengan sprint 3 yang dapat dilihat pada tabel berikut di bawah ini.

Tabel 4 Sprint 3 Form Input Data Perekrutan

\begin{tabular}{|c|c|c|c|}
\hline $\begin{array}{c}\text { Fitur } \\
\text { Backlog }\end{array}$ & Task & $\begin{array}{c}\text { Pemilih } \\
\text { Task }\end{array}$ & $\begin{array}{c}\text { Perkiraan } \\
\text { Waktu } \\
\text { (hari) }\end{array}$ \\
\hline \multirow{6}{*}{$\begin{array}{l}\text { Membuat } \\
\text { form input } \\
\text { data } \\
\text { perekrutan }\end{array}$} & $\begin{array}{c}\text { Desain } \\
\text { Interface }\end{array}$ & $\begin{array}{l}\text { Analis } \\
\text { Sistem }\end{array}$ & 2 hari \\
\hline & $\begin{array}{c}\text { Desain } \\
\text { Database }\end{array}$ & $\begin{array}{c}\text { Database } \\
\text { Sistem }\end{array}$ & 2 Hari \\
\hline & $\begin{array}{c}\text { Coding } \\
\text { Front } \\
\text { End }\end{array}$ & Programmer & 5 Hari \\
\hline & $\begin{array}{c}\text { Coding } \\
\text { Back } \\
\text { End }\end{array}$ & Programmer & 5 Hari \\
\hline & Testing & $\begin{array}{c}\text { Project } \\
\text { Manager }\end{array}$ & 2 Hari \\
\hline & \multicolumn{2}{|c|}{ Total } & 16 \\
\hline
\end{tabular}

Sprint 3 ini terdiri dari 5 task dan memiliki total estimasi waktu sebanyak 16 hari dan product backlog pada print ini fokus untuk input data perekrutan pegawai, setelah selesai dilanjut mengerjakan sprint 4 pada tabel di bawah ini.

\section{Tabel 5 Sprint 4 Form Input Data Pegawai Baru}

Sprint 4 terdiri dari 5 task dan memiliki total estimasi waktu sebanyak 16 hari dan product backlog pada sprint ini difokuskan pada penginputan data pegawai baru yang telah di approve, berikutnya adalah sprint 5 yang dapat dilihat pada tabel 6 di bawah ini.

Tabel 6 Sprint 5 Form Input Data Pegawai dan SK Kerja

Sprint 5 memiliki 5 task dengan total estimasi waktu sebanyak 16 Hari. Product backlog pada sprint 4 difokuskan pada kebutuhan untuk input Data pegawai yang sudah memiliki SK kerja. 


\begin{tabular}{|c|c|c|c|}
\hline $\begin{array}{c}\text { Fitur } \\
\text { Backlog }\end{array}$ & Task & $\begin{array}{c}\text { Pemilih } \\
\text { Task }\end{array}$ & $\begin{array}{c}\text { Perkiraan } \\
\text { Waktu } \\
\text { (hari) }\end{array}$ \\
\hline \multirow{6}{*}{$\begin{array}{c}\text { Membuat } \\
\text { Form Input } \\
\text { Data } \\
\text { Pegawai } \\
\text { dan SK } \\
\text { Kerja }\end{array}$} & $\begin{array}{c}\text { Desain } \\
\text { Database }\end{array}$ & $\begin{array}{c}\text { Database } \\
\text { Sistem }\end{array}$ & 2 hari \\
\hline & $\begin{array}{l}\text { Desain } \\
\text { Interface }\end{array}$ & $\begin{array}{l}\text { Analis } \\
\text { Sistem }\end{array}$ & 2 Hari \\
\hline & $\begin{array}{l}\text { Coding } \\
\text { Front End }\end{array}$ & Programmer & 5 Hari \\
\hline & $\begin{array}{c}\text { Coding } \\
\text { Back End }\end{array}$ & Programmer & 5 Hari \\
\hline & Testing & $\begin{array}{l}\text { Project } \\
\text { Manager }\end{array}$ & 2 Hari \\
\hline & \multicolumn{2}{|c|}{ Total } & 16 \\
\hline
\end{tabular}

Tabel 7 Sprint 6 Form Input Data Keahadiran

\begin{tabular}{|c|c|c|c|}
\hline $\begin{array}{c}\text { Fitur } \\
\text { Backlog }\end{array}$ & Task & Pemilih Task & $\begin{array}{c}\text { Perkiraan } \\
\text { Waktu } \\
\text { (hari) }\end{array}$ \\
\hline \multirow{4}{*}{$\begin{array}{c}\text { Membuat } \\
\text { Form Input } \\
\text { Data } \\
\text { Kehadiran }\end{array}$} & $\begin{array}{c}\text { Desain } \\
\text { Database }\end{array}$ & $\begin{array}{c}\text { Database } \\
\text { Sistem }\end{array}$ & 2 hari \\
\cline { 2 - 4 } & $\begin{array}{c}\text { Desain } \\
\text { Interface }\end{array}$ & Analis Sistem & 2 Hari \\
\cline { 2 - 4 } & Back End & Programmer & 5 Hari \\
\cline { 2 - 4 } & Pesting & $\begin{array}{c}\text { Project } \\
\text { Manager }\end{array}$ & 2 Hari \\
\cline { 2 - 4 } & \multicolumn{2}{|c|}{ Total Hari } \\
\cline { 2 - 4 }
\end{tabular}

Sprint 6 terdiri dari 5 task dan memiliki total estimasi waktu sebanyak 16 hari dan product backlog pada sprint ini difokuskan pada penginputan data kehadiran pegawai, sehingga memudahkan bagian HRD dalam merekap semua data kehadiran pegawai, dan berikutnya adalah sprint 7 yang dapat dilihat pada tabel 8 di bawah ini.

\section{Tabel 8 Sprint 7 Form Input Data penggajian}

Sprint 7 terdiri dari 5 task dan memiliki total estimasi waktu sebanyak 16 jam. Setelah sprint 7 selesai dilaksanakan, maka dilanjutkan dengan sprint 8 yang dapat dilihat pada table 9 berikut di bawah ini.



\begin{tabular}{|c|c|c|c|}
\hline $\begin{array}{c}\text { Fitur } \\
\text { Backlog }\end{array}$ & Task & $\begin{array}{c}\text { Pemilih } \\
\text { Task }\end{array}$ & $\begin{array}{c}\text { Perkiraan } \\
\text { Waktu } \\
\text { (hari) }\end{array}$ \\
\hline \multirow{4}{*}{$\begin{array}{c}\text { Membuat } \\
\text { Form Input } \\
\text { Data } \\
\text { Penilaian } \\
\text { Kinerja }\end{array}$} & $\begin{array}{c}\text { Desain } \\
\text { Database }\end{array}$ & $\begin{array}{c}\text { Database } \\
\text { Sistem }\end{array}$ & 2 hari \\
\cline { 2 - 4 } & $\begin{array}{c}\text { Desain } \\
\text { Interface }\end{array}$ & $\begin{array}{c}\text { Analis } \\
\text { Sistem }\end{array}$ & 2 Hari \\
\cline { 2 - 4 } & $\begin{array}{c}\text { Coding } \\
\text { Back End }\end{array}$ & Programmer & 5 Hari \\
\cline { 2 - 4 } & Programmer & 5 Hari \\
\cline { 2 - 4 } & \multicolumn{2}{|c|}{$\begin{array}{c}\text { Total } \\
\text { Troject }\end{array}$} & 2 Hari \\
\cline { 2 - 4 }
\end{tabular}

Sprint 8 terdiri dari 5 task dan memiliki total estimasi waktu sebanyak 16 hari dan product backlog pada sprint ini difokuskan pada penginputan data Penilaian Kinerja pegawai, yang nantinya menjadi acuan manajer dalam pengambilan keputusan terhadap kenaikan ataupun promosi jabatan, dan berikutnya adalah sprint 9 yang dapat dilihat pada tabel 10 di bawah ini.

Tabel 10 Sprint 9 Form Input Data Sanksi Pegawai

Sprint 9 terdiri dari 5 task dan memiliki total estimasi waktu sebanyak 16 hari dan product backlog pada sprint 


\begin{tabular}{|c|c|c|c|}
\hline $\begin{array}{c}\text { Fitur } \\
\text { Backlog }\end{array}$ & Task & Pemilih Task & $\begin{array}{c}\text { Perkiraan } \\
\text { Waktu } \\
\text { (hari) }\end{array}$ \\
\hline \multirow{7}{*}{$\begin{array}{c}\text { Membuat } \\
\text { Form Input } \\
\text { Data Sanksi } \\
\text { pegawai }\end{array}$} & $\begin{array}{c}\text { Desain } \\
\text { Database }\end{array}$ & $\begin{array}{c}\text { Database } \\
\text { Sistem }\end{array}$ & 2 hari \\
\cline { 2 - 4 } & $\begin{array}{c}\text { Desain } \\
\text { Interface }\end{array}$ & $\begin{array}{c}\text { Analis } \\
\text { Sistem }\end{array}$ & 2 Hari \\
\cline { 2 - 4 } & Back End & Programmer & 5 Hari \\
\cline { 2 - 4 } & Programmer & 5 Hari \\
\cline { 2 - 5 } & Testing & Project & 2 Hari \\
\cline { 2 - 5 } & \multicolumn{2}{|c|}{ Total } & 16 \\
\hline
\end{tabular}

ini difokuskan pada penginputan data Sanksi pegawai, yang nantinya menjadi acuan manajer dalam pengambilan keputusan terhadap kenaikan ataupun promosi jabatan untuk pegawai.

\section{Menentukan Scrum Meeting}

Aktifitas berikutnya yang menjadi bagian dari tahapan scrum model adalah melaksanakan scrum meetings yang dijadwalkan rutin perhari pada pukul 09.00 hingga pukul 10.30. Agenda meeting harian ini dilakukan dalam rangka mengevaluasi pekerjaan yang telah diselesaikan, kendala yang dihadapi serta solusi dan target penyelesaian sebagai bahan pertemuan berikutnya.

\section{Demos}

Tahapan selanjutnya dalam Scrum adalah demo yang dilaksanakan untuk memberi informasi kepada klien peningkatan dari perangkat lunak yang telah dihasilkan dan dapat langsung dievaluasi oleh klien. Hasil tampilan dari pembangunan sistem informasi Pencatatan dan Pendatan Manajemen SDM, dapat dijelaskan dimulai dari halaman utama aplikasi seperti gambar berikut:

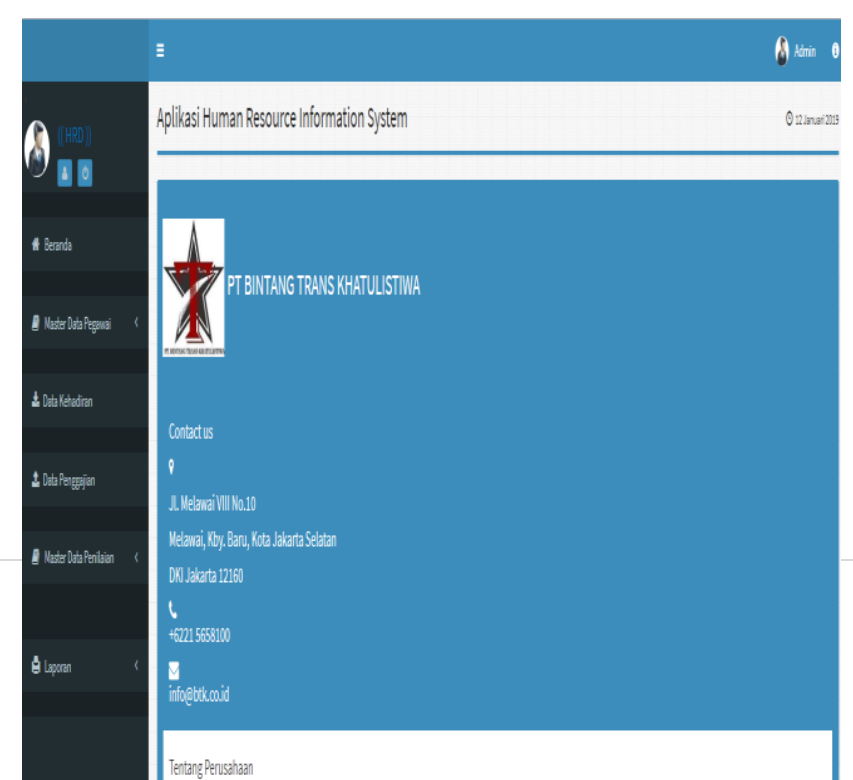

\section{Gambar 5. Halaman Utama Aplikasi}

Gambar 5 di atas merupakan tampilan utama dari aplikasi setelah user berhasil memasukkan sandi dengan benar pada halaman login, dan selanjutnya pengelolaan data pegawai dapat dilihat pada gambar dibawah ini:

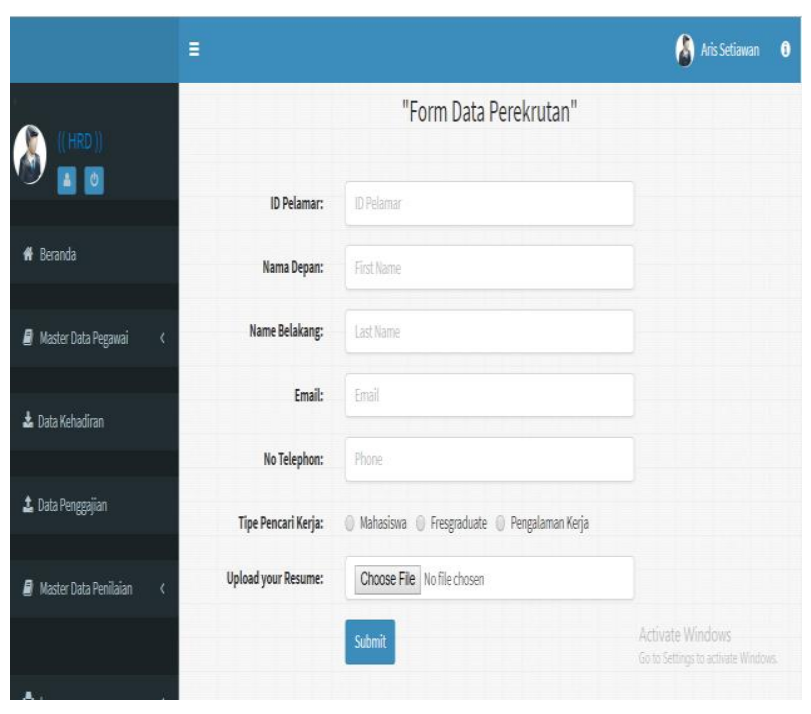

\section{Gambar 6. Halaman Form Input data Rekrutment}

Pada menu Data Rekrutmen terdiri dari informasi mengenai data perekrutan terdapat opsi atau pilihan aksi submit untuk mengupload berkas data pegawai. 


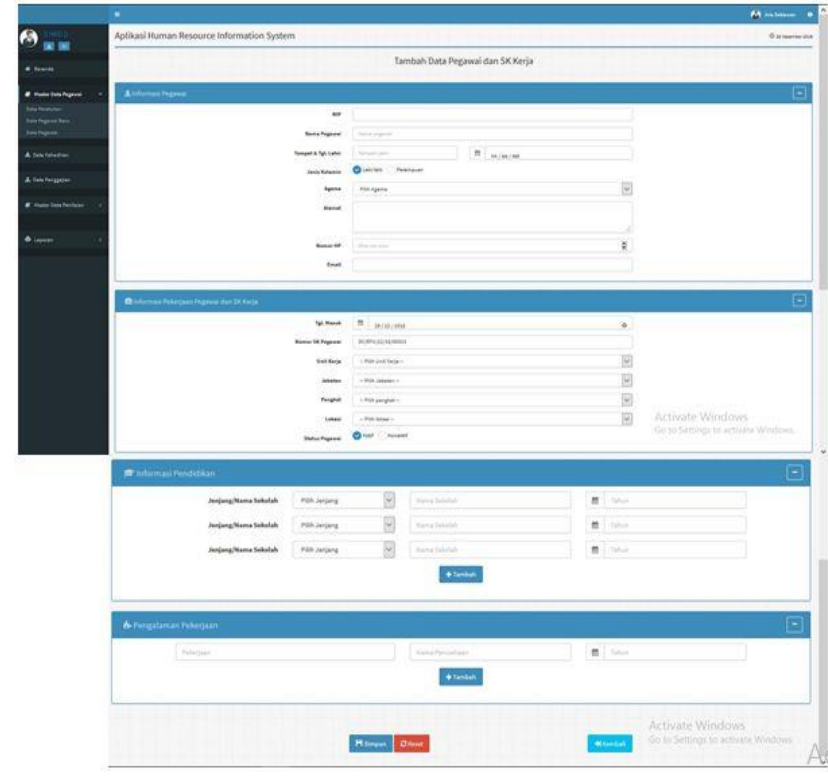

\section{Gambar 7. Halaman Form data Pegawai \& SK kerja}

Dimenu Data Pegawai dan SK Kerja dapat dilihat informasi data mengenai data pegawai yang sudah mendapatkan SK kerja beserta jabatan yang dimiliki.

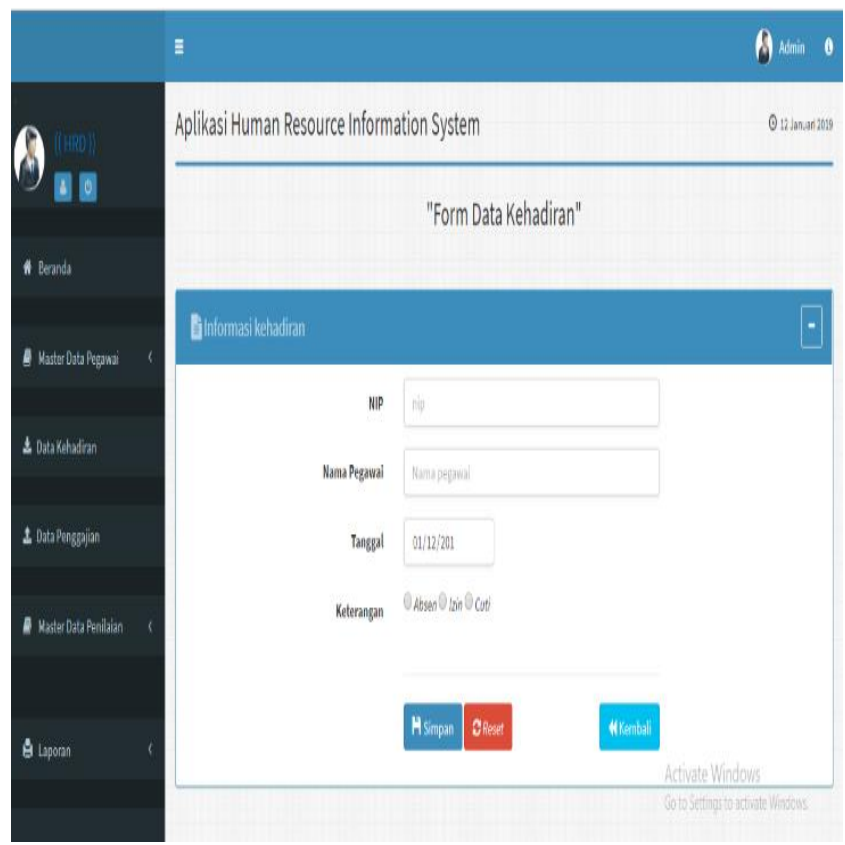

\section{Gambar 8. Halaman Menu Data Kehadiran}

Di menu data kehadiran berisi tentang riwayat kehadiran pegawai yang terdiri dari absen, sakit dan cuti, terdapat opsi atau pilihan simpan dan reset.

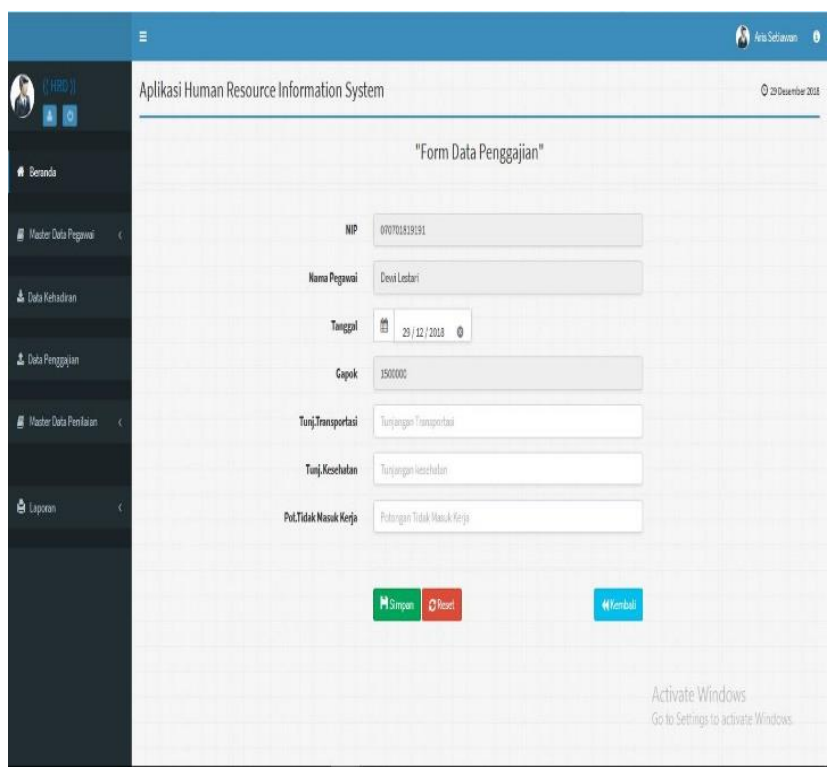

Gambar 9. Halaman Menu Data Penggajian

Pada menu data penggajian yaitu pengelolaan tentang penggajian yang dihitung berdasarkan kehadiran dan gaji pokok (standar) untuk setiap jabatan yang akan di akumulasi dengan berbagai tunjangan dan pengurangan dari riwayat kehadiran pegawai.

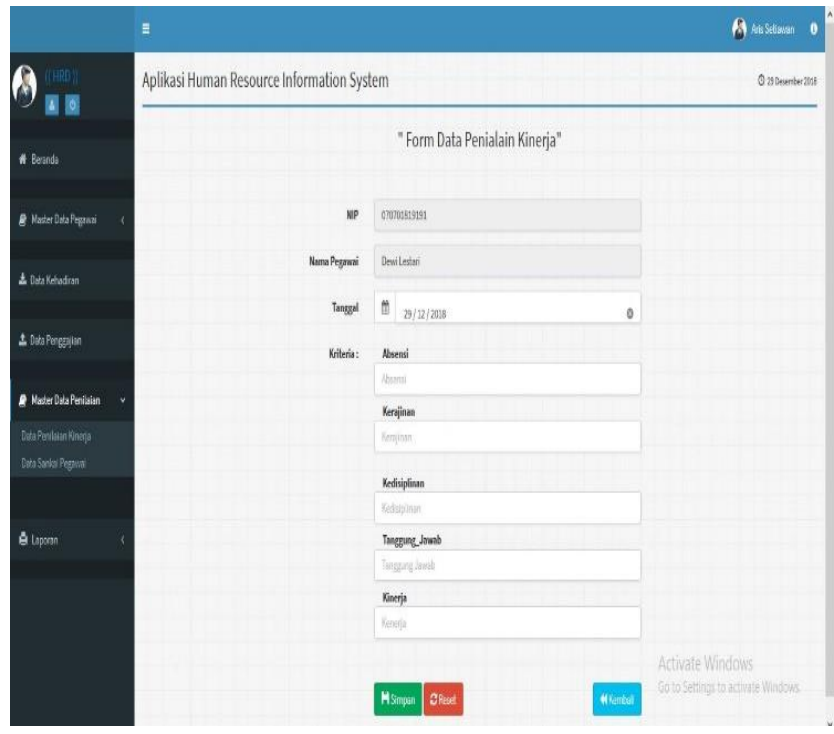

Gambar 10. Halaman Menu Data Penilaian Kinerja

Dalam menu data penilaian kinerja ini dapat dilihat tentang kinerja pegawai yang di dasarkan dari berbagai kriteria seperti absensi, kerajinan, kedisiplinan dan tanggung jawab pada setiap tugas kerja yang diberikan, yang nantinya data ini bisa dijadikan sebagai acuan bagi 
manajer/pimpinan dalam pengambilan keputusan salah satunya untuk kenaikan pangkat atau promosi jabatan.

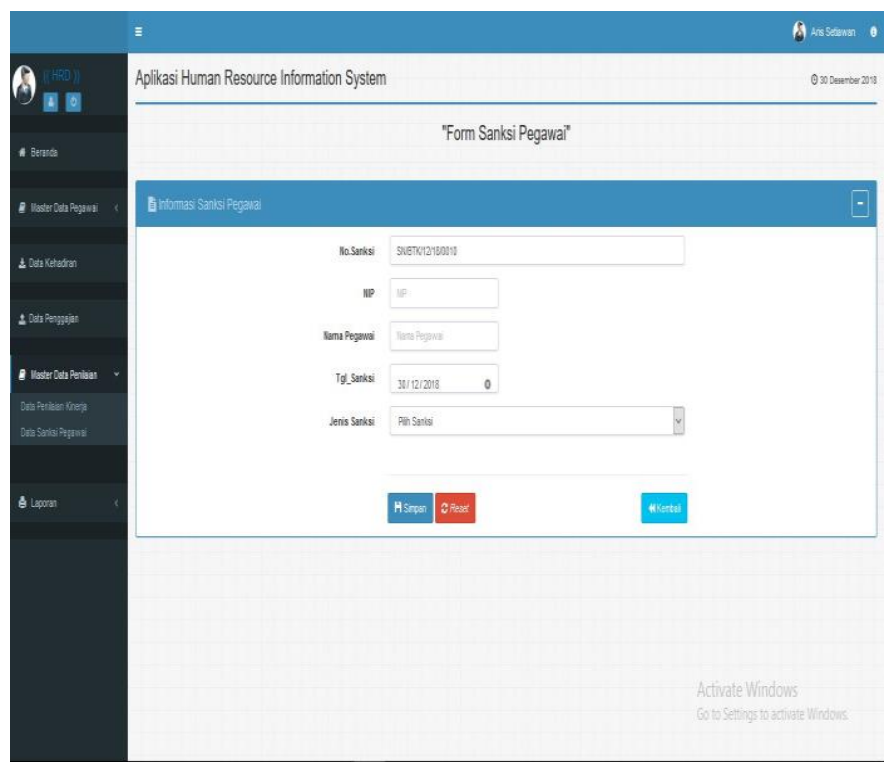

\section{Gambar 11. Halaman Menu Data Sanksi}

Dalam menu data Sanksi dapat dilihat tentang sanksi yang tealah diterima oleh pegawai dalam masa tugasnya, data ini juga nantinya bisa dijadikan sebagai acuan bagi manajer/pimpinan dalam pengambilan keputusan salah satunya untuk kenaikan pangkat atau promosi jabatan.

\section{KESIMPULAN}

Berdasarkan penelitian yang telah dilakukan, maka dapat ditarik kesimpulan yaitu dengan adanya Aplikasi Sistem Pencatatan dan Pendataan Manajemen Sumber Daya Manusia pada sistem kerja dibagian HRD yang dapat mempermudah proses pendataan tentang informasi mengenai data pegawai yang lebih efektif dan efisien pada perusahaan PT bintang Trans Khatulistiwa (BTK) seperti pendataan data personal pegawai, pendataan absensi, pendataan izin dan cuti karyawan, proses penggajian (payrol), penilaian kinerja pegawai, dan pendataan sanksi atau hukuman pegawai.

\section{DAFTAR PUSTAKA}

[1] Wulandari, Ainul Fitriyah \& Yuni Yamasari. 2012. Sistem Informasi Manajemen Sumber Daya
Manusia (Studi Kasus Bumida Syariah). Jurnal Informatika. Vol. 01 No. 01.

[2] Abdurahman, Muhdar. 2018. Sistem Informasi Data Pegawai Berbasis Web Pada Kementerian Kelautan Dan Perikanan Kota Ternate. Jurnal Ilmiah KOMINFO Vol.01 N0.02, E-ISSN: 26214970, P-ISSN: 2621-4962.

[3] Ongkorahardjo, , M. D., Susanto, , A., \& Rachmawati , D. 2018. Analisis Pengaruh Human Capital Terhadap Kinerja Perusahaan (Studi Empiris pada Kantor Akuntan Publik di Indonesia). Jurnal Akutansi dan Keuangan Vol 10 No.1.

[4] Buwono, Robby Cokro, Ema Utami, \& Eko Boedijanto. 2012. Rancang Bangun Sistem Informasi Sumber Daya Manusia (Studi Kasus Di Pt. Diginet Media Yogyakarta). Jurnal Teknologi Informasi Vol. VII Nomor 19, ISSN : 1907-2430.

[5] Putra, A. M. 2015. Indikator Keberhasilan Kinerja Individu dengan Locus of Control dan Kepribadian S ebagai Variabel Independen. Jurnal Perilaku dan Strategi Bisnis Vol 3 No. 26.

[6] Sahangggamu, P. M., \& Mandey, S. L. 2014. Pengaruh Pelatihan Kerja, Motivasi, dan Disiplin Kerja Terhadap Kinerja Karyawan Pada PT Bank Pengkreditan Rakyat Dana Raya. Jurnal EMBA Vol 2 No.4.

[7] Atikwati, E. 2016. Strategi Rekrutmen dan Seleksi terhadap Kinerja Karyawan. Jurnal Perilaku dan Stategi Bisnis Vol 4 No.1.

[8] Jonni, Muhammad \& Syepry Maulana Husain. 2016. Perancangan Aplikasi Human Resource Information System (HRIS) Berbasis Website Pada PT. Super Tata Raya Steel. Jurnal Teknik UMT, Volume 5, No. 2, ISSN 23028734.

[9] Purnomo, Rastiko Wulan. 2014. Pembangunan Sistem Informasi Pengolahan Data Pegawai Pada Sekolah Dasar (SD) Negeri Temon 4 Kecamatan Arjosari Pacitan. Indonesian Journal on Networking and Security (IJNS) Volume 3 No 4, ISSN: 2302-5700. 
[10] Pressman, Roger S. 2010. Software Engineering, A practitioner's Approach. 7th edition. McGraw-Hill, Inc., New York.

[11] Scarvada, A.J., Tatiana Bouzdine-Chameeva, Susan Meyer Goldstein, Julie M. Hays, Arthur V. Hill. 2004. A Review of the Causal Mapping Practice and Research Literature. 